3. Мустафина Ф.Ш. Методика обучения иностранным языкам и воспитания: учебное пособие. [Электронный ресурс]: учебное пособие. - Электрон. дан. - БГПУ имени М. Акмуллы (Башкирский государственный педагогический университет им. М. Акмуллы) / 2015 - 284 с.

4. Соловова Е.Н. Методика обучения иностранным языкам: базовый курс лекций: пособие для студентов пед. вузов и учителей / Е.Н. Соловова. - 3-е изд. - М. : Просвещение 2005.

\title{
Система персонажей героического эпоса-олонхо: выразительные средства языка и перевод (на материале олонхо П. Оготоева «Элэс Боотур»)
}

\author{
Бурцева А.А., студентка, \\ Северо-Восточный федеральный университет, \\ 2. Якутск \\ E-mail: aburtseva97@gmail.com
}

Научный руководитель: к.ф.н., доцент Собакина И.В.

Олонхо - это удивительный пласт якутской культуры, своими корнями уходящий в глубь веков, а олонхо «Элэс Боотур» - один из выдающихся памятников устного творчества народа саха, в котором поразительной силы художественный язык передает борьбу двух противоположных сил.

В олонхо выдающегося якутского олонхосута Петра Васильевича Оготоева «Элэс Боотур» всего 46 персонажей. Их можно разделить на следующие группы: богатыри срединного, верхнего, нижнего миров, жители срединного и нижнего миров, удаганки срединного и нижнего миров, духи и животные. При передаче образов персонажей олонхо «Элэс Боотур» были использованы выразительные средства языка эпитеты, парные слова, сравнения, слова с повторением основы, фразеологизмы которые представляют собой особый пласт якутского языка, они помогают речи быть красочной, выразительной и богатой:

Парные слова. В якутском языке любая часть речи, член предложения образует парное слово, тем самым расширяет и усиливает значение слова, а иногда образует множественное число: Албан-дьоһун ааттаах - прославленный, Хап-хара хаастардаах - брови черные, Кэрэ-чуор кулгаахтардаах - чуткие уши.

Слова с повторением основы (редупликация) в рассматриваемом олонхо представлено большинством частей речи. Это выразительное средство языка усиливает значение и придает акцент: кӥндӥттэн-кӥндӥ - дороже которой не найти, кӧрӧртӧн кӧрӧ-сӥоргӥ ӥчӥгэй - взгляд очей лучистых счастье обещуает, ӧлӧ-ӧлӧ тиллэр - где трижды он умрет, кэрэттэн кэрэ бэйэлээх - девушка юная красоты невиданной, минньигэс-минньигэстик мичилийэн - в улььке сладкой.

Эпитет - это красочное, выразительное определение, которое основывается на скрытом сравнении. Подчеркивает особенности описываемого объекта, его самые выразительные черты: алтан уууох - золотые кости, суон модун сурахтаах - слава о силе небывалой, не находящей себе равных, бабыа кӧмӥс тарбахтардаах - десять 
пальцев ловких, ухватистых, оонньуур хааннаах - кровь бурливая, тимир килиэ киһи существо железное.

Сравнение - слово или выражение, в основе которого лежит сопоставление одного предмета с другим. Чаще всего оформляется оно в виде сравнительного оборота: суллаабыт тиит курдук суон дулаğа сотолоох- голени крепкие, как комли деревянные, алта былас кэриүэ дарайар сарыннаах - плечей ширина шесть саженей, чаан олгуй сайа тӧбӧлӧо - голова что котел огромный, харалаабыт хотуурдары хардарыта туппут курдук хара дэгиэ тылырахтардаах - когти острые, иепкие, как косы черные, киирэн эрэр кӥн килбиэнин курдук кэрэ бэйэлээх - заходящего солнща заре подобен румянеи ее, куба курдуук устан - плыла навстречу лебедем бельм.

Фразеологизм - устойчивое сочетание слов, усиливающее значение, в рассматриваемом олонхо встречается редко: Кӧччӧх гынан кӧтӥппӥт - одаривщую крылами сильными, духом несгибаемылм.

При передаче образов персонажей олонхо «Элэс Боотур» были использованы следующие способы перевода:

1. Эквивалентный перевод - равнозначная передача языковых единиц, принадлежащих к различным языковым системам, или отдельных частей текста перевода и текста оригинала.

Например: Ağыс былас cyhyoxmaax - Having eight-sagened hair; Küн улуyhyн кӥйстээхтэрэ - Силачи улуса солнечного.

2. Адекватный перевод - замена части высказывания на исходном языке высказыванием или частью высказывания на языке перевода с другим значением, но с той же смысловой и/или эмоциональной функцией.

Например: Кӥӧгэйэр кӥммэр -In mу уоung years. Ситэри силгэлээх, Мӧлтӧӧбӧт быччыңнаах, Хайа астахха Хаан тахсыбат, Дьӧлӧ астахха Дьйһӥн уларыйбат Ӧлбӧт ӥӧстээх. - С мышщами крепкими, Что кровь не выступает Из резаных ран, С мускулами, что не дрогнут От колотой раны.

3. Генерализация - более узкое значение заменяется на более широкое, создаваемое соответствие выражает родовое понятие, включающее исходное видовое. При переводе олонхо этот прием исользуется довольно часто, так как олонхо изобилует чрезмерной детализацией.

Например: Сырдык сыдьаай сэбэрэлээх - Светлолицая; Туспа дойду Туллубат тулааһьннара, Атын сир Албан-дьоһун ааттаахтара. - Famous people of other lands.

4. Перестановка как вид переводческой трансформации - это изменение расположения (порядка следования) языковых элементов в тексте перевода по сравнению с текстом подлинника. Элементами, подвергающимися перестановке, являются обычно слова, словосочетания, части сложного предложения, имеющие фиксированную позицию в якутском предложении и самостоятельные предложения в строе текста.

Например: Киирэн эрэр кӥн Килбиэнин курдук Кэрэ бэйэлээх - A girl shining like the setting sun; Ă̆ыс анньар инньэлээх, То̆̆ус торсуйар тумустаах Дуолан Дуксуула обургу - Дуолан Дуксуула С восемью колющими иглами С девятью клюющими клювами

5. Опущение - при переводе опущению подвергаются чаще всего слова, являющиеся семантически избыточными, то есть выражающие значения, которые могут быть извлечены из текста и без их помощи. Как система любого языка в целом, так и конкретные речевые произведения, в том числе и эпос-олонхо, обладают, как 
известно, весьма большой степенью избыточности, что дает возможность производить те или иные опущения в процессе перевода без ущерба для содержания.

Например: Хара хаан олбохтоох. Хаан Сарахайдаан диэн Улуу удайан дьаальь Aammaax dbaxmap ağacmaaxnblн. - My cousin is a greate witch Khaan Sarakhaidaan; Тӥорт кырыьллаах Тимир килиэ киһи - The four-edged iron man

6. Добавление. В некоторых случаях для того, чтобы правильнее и понятнее передать смысл, выразить идею исходного материала переводчику необходимо ввести несколько дополнительных слов. Добавления при переводе олонхо обусловлены различиями синтаксиса, грамматики, отсутствием лексико-семантических эквивалентов в языке перевода, а также требованиями стилистики языка.

Например: Сотуун тириитэ сонноох - Пальто из кожи скота, Падшего от язвығ; А ğаттан айылльббытылм - My descent and birth

Рассмотрев переводы на русский и анлийский языки, можно сделать вывод, что перевод на русский язык выполнен на достаточно высоком уровне. Многие описания сохранены, точно переданы. Дословный перевод, препятствующий понимаю текста, не наблюдается, перевод получился качественным. Что касается перевода на английский язык, к сожалению, следует отметить наличие опущений, которые приводят к недосказанности в описаниях персонажей олонхо. В олонхо очень много описаний характеров, действий персонажей, а в переводе многое из этого не передано, что несомненно влияет на восприятие англоязычным читателем Шедевра устного нематериального культурного наследия человечества - героического эпоса-олонхо.

\title{
Образ укрепления российского рубля в экономических карикатурах на корейском и английском языках
}

\author{
Васильев Ю.А., студент, \\ Северо-Восточный федеральный университет, \\ 2. Якутск, \\ E-mail: julianandreevich@gmail.com
}

\section{Научный руководитель: старший преподаватель Иванова А.В.}

В 2014 году на долю российской экономики выпало тяжелое бремя: Западные страны ввели санкции, конфликт с Украиной обострился, рост экономики заметно замедлился, цены на нефть упали. И все это привело к тому, что динамика курса рубля начала подвергаться резким колебаниям.

2015 год был весьма непростым для российской экономики. Скачки валюты, начавшиеся в 2014-м, продолжились и в 2015 году. На 1 января ЦБ установил курс доллара в размере 56,24 руб. По окончании новогодних каникул, 13 января, в условиях продолжавшегося падения стоимости нефти на мировом рынке Банк России зафиксировал курс доллара на отметке 62,73 руб. Затем отечественная валюта продолжила снижаться в цене. 24 января рубль несколько подорожал (доллар подешевел с 65,40 до 63,39 руб.). Но уже 27 января его падение возобновилось. В конце января Банк России снизил ключевую ставку с 17\% до 15\%. Это послужило одной из причин очередного ослабления рубля. Начиная с конца февраля рубль начал 